\title{
On the Way to Real Applications: Aluminum Matrix Syntactic Foams
}

\author{
Çağın Bolat $\mathbb{1}$, İsmail Cem Akgün $\mathbb{1}$, Ali Gokşenli \\ Istanbul Technical University, Faculty of Mechanical Engineering, Beyoglu, Istanbul, Turkey
}

\begin{abstract}
In recent times, aluminum matrix syntactic foams (AMSFs) have become considerably attractive for many industries such as automotive, aviation, aerospace and composite sector due to their features of low density, good compression strength, perfect energy absorption capacity and good ductility. Since the AMSF includes filler materials providing high porosity, it can be also named as composite foam and can be placed between traditional metal foams and particle reinforced composites. Glass and ceramic hollow spheres, fly ash cenospheres and ceramic porous materials are usually used in the AMSFs, but, lately, different types of fillers being cheaper and stronger have also being investigated. Although many scientific efforts have been made for the last decade to understand mechanical and physical properties of these advanced materials, studies have mainly been performed on relatively small size samples and remained in laboratory. Therefore, there is still room for improvement in terms of fabrication techniques. In this paper, our aims are to scrutinize newest studies about ASMFs, to create new viewpoints and to introduce an alternative bright perspective for probable real applications.
\end{abstract}

Keywords: aluminum alloys, syntactic foam, microstructure, compression response, fracture mechanism

\section{INTRODUCTION}

Syntactic foam is an advanced engineering material composing of hollow or porous ceramic particles and a polymer or metal matrix. Even though polymer matrix syntactic foams (PMSFs) have become commercial for some time, metal matrix syntactic foams (MMSFs) have not been investigated in detail and have been fabricated only in laboratory scale till the recent years. Fig. 1 given below demonstrates some syntactic foam samples produced with casting methods.

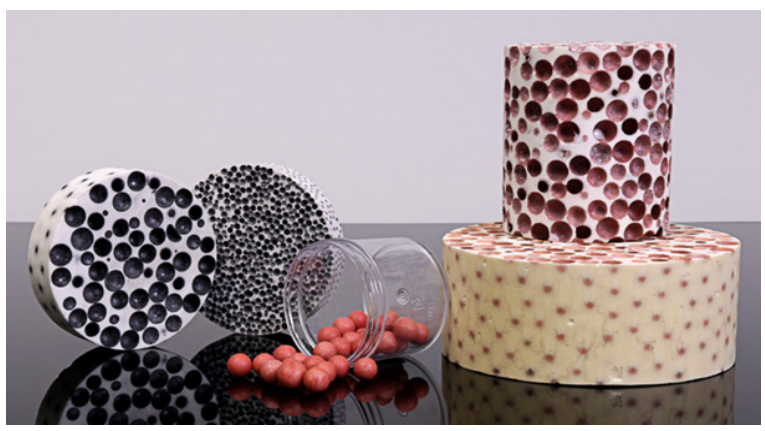

Figure 1. Some examples of MMSF and PMSF materials [1]

Compared to other MMSFs, nowadays, AMSFs have been notably popular due to their unique properties like low density, good strength under compressive loadings, perfect energy absorption capacity and noteworthy ductility. They can be either considered as particle reinforced composites or can be interpreted as closed cell metal foams by reason of their original inner structure [2]. The synergetic effect between $\mathrm{Al}$ matrix and filler particle plays an important role both for mechanical and physical features.

As matrix materials, commercially pure (cp-Al), A356, A380, 2014, 6061 and 7075 series are frequently used while the reinforcement is usually fabricated from ceramics comprising of some kinds of oxides or from natural sources (porous rocks and stones) and metals [3-5]. It is clear from the technical literature that spherical hollow $\mathrm{Al}_{2} \mathrm{O}_{3}, \mathrm{SiC}, \mathrm{SiO}_{2}$ ceramics and fly ash cenospheres are common reinforcement materials [6-8]. Although these thin walled ceramic hollow spheres display good physical and mechanical performance, owing to their manufacturing process they can be counted relatively expensive. However, recently, natural based porous fillers have been started to be used by researchers being interested in $\mathrm{Al}$ foams. Pumice, which is a porous rock being formed as a result of volcanic eruptions, and expanded perlite (cousin of pumice) are good examples for this situation. Thanks to these natural fillers, desired mechanical features also could be reached with low production cost [5], [9].
* Corresponding authour

Email: caginbolat@itu.edu.tr
European Mechanical Science (2020), 4(3): 131-141 doi: https://doi.org/10.26701/ems.703619

Received: March 16, 2020

Accepted: July 16, 2020 
It is obvious that total porosity of the foam is majorly controlled by fillers own porosity [10]. In addition to this, certain shrinkage cavities forming between matrix and filler interfaces or in matrix itself can lead to porosity increment [11]. Density and total porosity of the filler are also decisive for final foam density. In some cases, filler materials tend to combining or they leak into the hollow spheres from surface cracks and defects, which results in unwanted high density foam [12].

Low melting point, availability of heat treatment (2XXX, 6XXX and 7XXX series) and relatively low density are main advantageous properties of $\mathrm{Al}$ alloys [13]. Application potential of AMSFs is more promising in the automotive than the other sectors since it is a perfect candidate to provide some key requirements such as lightweight construction, energy absorption and damping insulation (i.e. crash boxes between impact beam and the front rail) [14]. Aside from improving engine technologies, total weight decrease is also very critical for the fuel efficiency and maintenance costs. Herein, AMSF parts can provide these requirements without any setbacks.

In this paper, fabrication methods, macroscopic/microscopic features and physical/mechanical properties of AMSFs were reviewed in detail in the light of past and recent literature efforts. Apart from well known traditional fillers, some new alternative fillers tried in the latest works were also stated. In addition, some probable future applications of these advance engineering foams were emphasized depending upon target industrial areas in order to provide broad perspective for the next studies about AMSFs.

\section{FABRICATION AND PHYSICAL/MECHANICAL PROPERTIES}

\subsection{Fabrication Methods}

Infiltration casting and dispersion technique are two main methods for manufacturing of the AMSFs and both of them consist of unlike sub methods shown in Table 1. All fabrication methods have some advantages and handicaps with regards of uniform distribution of fillers, casting defects (voids, pits and cavities), dimensional accuracy, surface quality and cost effectiveness.

Table 1. Fabrication Methods of AMSF

\begin{tabular}{|l|l|}
\hline \multicolumn{2}{|l|}{ Fabrication Methods } \\
\hline Infiltration Casting & Dispersion Casting \\
\hline - Pressure infiltration & - Stir casting \\
\hline - Counter gravity & - Centrifugal \\
\hline - Gas pressure & - Buoyancy method \\
\hline - Vacuum assisted & \\
\hline - High pressure & \\
\hline
\end{tabular}

Infiltration casting methods are often applied in different ways to produce AMSFs and other alternatives have still been investigated to improve physical and mechanical features. Many researchers have utilized infiltration casting methods to obtain uniform foam structure. Based on manufacturing method, process parameters shown in Fig. 2 might change.

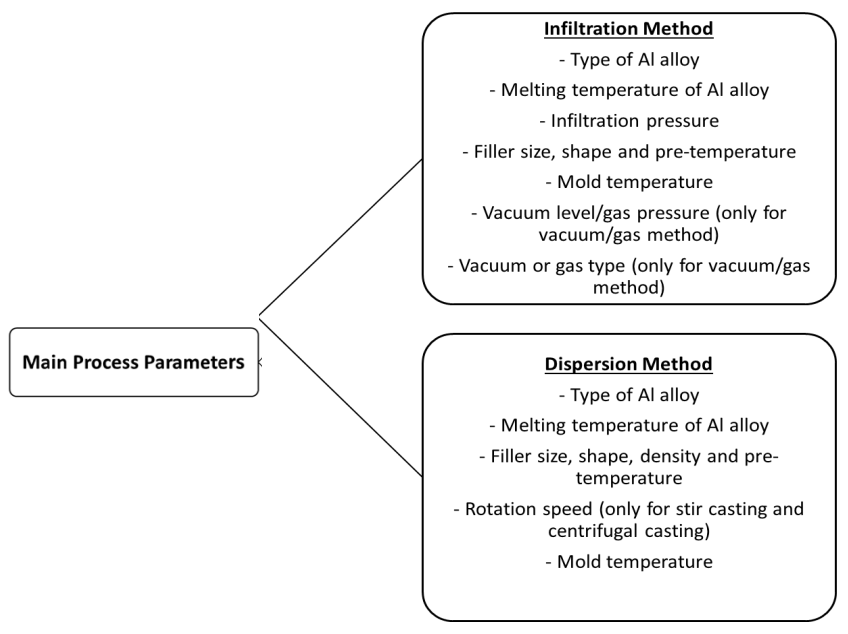

Figure 2. Main process parameters of AMSF fabrication

Pressure infiltration is a very common and preferable method in comparison with the other ways and it works with the principle of gravity assisted infiltration. Usually, preheated filler materials are placed into the bottom section of the die and molten $\mathrm{Al}$ alloy is poured on them before the main pressure. In a work performed by Zhang et al., cp-Al/ fly ash cenosphere syntactic foam was manufactured with pressure infiltration under a pressure of $0.8 \mathrm{MPa}$. At first, they sintered the cenospheres in a steel mold at $650^{\circ} \mathrm{C}$ to get preform. Then, an Al block was placed into the same mold for melting and finally infiltration pressure was applied with a ram [15]. Concordantly, Zhang et al. used Al-Mg alloy 5A06 (Mg 6 wt.\%) and glass cenospheres as matrix and filler materials while Tao et al. studied on Al 6082 alloy/porous 75-500 $\mu \mathrm{m}$ ceramic foam in another efforts by applying the same casting technique mentioned above [10], [16]. Zhao et al. tried a similar method for fabrication of $\mathrm{cp}-\mathrm{Al} /$ porous 0,25-4 mm ceramic foam with $20 \mathrm{~mm}$ diameter and $30 \mathrm{~mm}$ height. They used four different fillers that were free before the infiltration pressure of $4 \mathrm{MPa}$ [17]. Apart from these works, Weise et al. focused on another method that can be called high pressure infiltration because of the pressure interval of 5-20 MPa and the research group produced A380/ S60HS hollow microsphere foams at $730^{\circ} \mathrm{C}$ in the pre heated $\left(295^{\circ} \mathrm{C}\right)$ sleeve whose forward tip was sealed [18].

As an alternative method, counter gravity infiltration (backward) can be considered and it is used in some investigations by researchers. In this method, contrary to the standard gravity assisted method, matrix material is filtered between fillers against the gravitational force. In this technique, die design is highly important due to the control of the part dimensions (usually specially designed die design is required).Taherishargh et al. fabricated A356/expanded perlite(3-4 mm) syntactic foam with this principle. Firstly, a block of $\mathrm{Al}$ was placed in graphite crucible and a graphite mold filled with perlite particles was put on the A356 block. Then, the assembly was closed with stainless steel chamber and whole system was delivered to electrical furnace. At $720^{\circ} \mathrm{C}$, the assembly was removed from the furnace and finally, the graphite mold was pushed downwards by 
forcing the molten matrix into the mold for infiltration [19]. Besides, the same group produced A356/pumice (2-4 mm) syntactic foam having $27 \mathrm{~mm}$ diameter and $41 \mathrm{~mm}$ height with the same backward infiltration method [5].

In order to Al filtration, vacuum can be counted as a good solution and it has been applied by many investigators for years. Thanks to the applied vacuum, more infiltration flexibility can be provided for liquid Al matrix and even narrow gaps can be filled with the metal. Palmer et al. fabricated Al 1350, 5083 and 6061 syntactic foams by means of vacuum assisted infiltration. Fillers utilized in the study were ceramic microspheres (45 and $270 \mu \mathrm{m}$ diameters). If it is glanced at the method briefly, an alumina crucible was filled with the microspheres. When solid matrix block on the fillers melted, pressure of $450 \mathrm{kPa}$ was applied to provide downward infiltration [20]. Orbulov et al. benefited from Ar gas for infiltration of melted AlSi12 and Al99,5 alloys between 100-150 $\mu \mathrm{m}$ micro balloons and optimized infiltration temperature, time and pressure [21]. Dunand et al. designed custom built $\mathrm{Ar}$ gas pressure system to manufacture cp- $\mathrm{Al}$ and $\mathrm{Al} 7075$ matrix syntactics. A mixture of $45 \mathrm{vol} . \%$ crystalline mullite $\left(3 \mathrm{Al}_{2} \mathrm{O}_{3}-2 \mathrm{SiO}_{2}\right)$ and 55 vol.\% amorphous silica $\left(\mathrm{SiO}_{2}\right)$ microspheres with 15-75 $\mu \mathrm{m}$ was packed in graphite crucible, then a block $\mathrm{Al}$ alloy was placed above the microspheres. The system was heated under vacuum to melt the block at $720^{\circ} \mathrm{C}$ and 3,5 $\mathrm{MPa}$ pressure of Ar gas was introduced to the system in order to force molten alloy into empty spaces between microspheres [22]. Schultz et al. also worked on AlA206/SiC foams by implementing vacuum assisted infiltration and they found that 0.5 bar Ar gas pressure was enough for fully infiltration between $1 \mathrm{~mm}$ fillers at $750^{\circ} \mathrm{C}$ [23].

As for filler conditions, it can be said that there are two options for filler materials before the infiltration process: preform shape with sintering or free mixture without pre sintering. In the first option, the fillers are in physical con- tact despite the fact that in the second option the fillers are separated from each other by Al matrix. As a result of this situation, the mechanical responses will not be alike. Preform shape filler materials can transmit deformation cracks to one another so that crack propagation takes place easily. On the contrary, cracks are stopped by $\mathrm{Al}$ matrix in the foams fabricated with free mixed fillers.

Aside from the infiltration techniques, there are some different methods in which dispersion mechanism is worked fundamentally. Stir casting is one of these dispersive techniques that uses basically a mechanical stirring equipment and liquid $\mathrm{Al}$ chamber. The process is based on classic blending and is carried out at elevated temperatures. For example, Sahu et al. fabricated Al 2014/cenosphere syntactic with stir casting. At the beginning, fillers with $100 \mu \mathrm{m}$ diameter were preheated at $1000-1100^{\circ} \mathrm{C}$ and $\mathrm{Al}$ alloy was melted, then, before transferring to the preheated forming die, fillers were added into the molten alloy pool for stirring at $600-800 \mathrm{rpm}$ for 5-10 min [24]. In another study, when they examined dry sliding wear behavior of Al LM13/100-200 $\mu \mathrm{m}$ cenosphere syntactic foam, Mondal et al. availed stir casting method. At $670^{\circ} \mathrm{C}$, LM13 was melted, mixed preheated fillers at $900^{\circ} \mathrm{C}$ were added into the molten alloy, mechanical stirring at 250$300 \mathrm{rpm}$ for $15 \mathrm{~min}$ were carried out and the mixture was transferred to solidification die [25]. Mondal et al. also manufactured AlSi12Cu1Mg1/cenosphere(100-200 $\mu \mathrm{m})$ hybrid foams with different densities by means of $\mathrm{CaH}_{2}$ foaming agent [26]. Furthermore, in surveys carried out by Daoud et al., researchers proved that other kinds of MMSFs like $\mathrm{Mg}$ and $\mathrm{Zn} / \mathrm{fly}$ ash cenosphere $(150 \mu \mathrm{m})$ foams could be manufactured with stir casting by optimizing process parameters [27], [28].

Centrifugal casting is another dispersion technique by which AMSF can be fabricated by means of centrifugal force. This technique can be applied both for closed packed and loosely

\begin{tabular}{|c|c|c|c|}
\hline Technique & Advantages & Handicaps & Key Instructions \\
\hline \multirow{3}{*}{ Pressure Infiltration } & Simple application and mold design & Difficult for small size fillers & Pre-heating of the mold and fillers \\
\hline & Good wetting of fillers & Difficult for complex shapes & Avoiding from matrix/filler reaction \\
\hline & Homogenous foam structure & & Lubrication of the mold walls \\
\hline \multirow{2}{*}{$\begin{array}{l}\text { Counter gravity } \\
\text { infiltration }\end{array}$} & Uniform filler distribution & Not useful for micron level fillers & Optimizing of male/female mold temperature \\
\hline & No requirement for expensive apparatus & Difficult for complex shapes & True selection of mesh apparatus \\
\hline \multirow{3}{*}{$\begin{array}{l}\text { High pressure die } \\
\text { casting }\end{array}$} & Highly suitable for automation & Expensive for small quantity fabrication & Lubrication of sprue and mold walls \\
\hline & More promising for complex geometries & Extra design parameter (piston speed) & Finding of system regime duration \\
\hline & Controllable, rapid and repeatable & & Correct mold inlet design \\
\hline \multirow{3}{*}{$\begin{array}{l}\text { Gas/Vacuum Infilt- } \\
\text { ration }\end{array}$} & Good filtration from narrow gaps & Need for additional tanks and pumps & Optimizing of vacuum level \\
\hline & Proper for micron size fillers & Relatively expensive than pressure infiltration & Right determination of gas pressure \\
\hline & Uniform foam structure & & Pre-heating of the mold and fillers \\
\hline \multirow[t]{2}{*}{ Stir casting } & Effective matrix/filler mixing & Requirement of secondary treatments & Avoiding from jellying \\
\hline & Simple fabrication components & & Correct mixing time \\
\hline \multirow{2}{*}{ Centrifugal casting } & Homogenous circular foam structure & Limited with circular geometry & Determination of optimum rotation speed \\
\hline & Controllable setup & & Designation of casting temperature \\
\hline \multirow[t]{2}{*}{ Buoyancy technique } & Very simple application & Useless for high density reinforcements & Ensuring density range of fillers \\
\hline & Low cost equipment and control & Not useful for bigger and sophisticated forms & Avoiding from filler/matrix reaction \\
\hline
\end{tabular}


aligned filler particles. When Ferreira et al. worked on corrosion behavior of $\mathrm{A} 356 / \mathrm{SiO}_{2}-\mathrm{Al}_{2} \mathrm{O}_{3}$ hollow micro balloon syntactic foams, they used centrifugal casting for sample production. At $630^{\circ} \mathrm{C}$, inside a resistance furnace, $\mathrm{Al}$ alloy and hollow fillers were mixed mechanically under protective $\mathrm{N}_{2}$ atmosphere. After the mixing, system temperature was escalated $850^{\circ} \mathrm{C}$ for casting with $750 \mathrm{rpm}$ rotational speed [29]. In some cases, because filler density is lower than that of the molten metal and they are not packed closely, heterogeneous volume distribution of the fillers can be beheld from the rotation axis to mold end [3]. Buoyancy technique is a simple dispersion strategy and it can also be utilized for fabrication of syntactics. Basically, thanks to density difference, low density filler particles prone to floating on the molten matrix and take form in the die. Kim et al. fabricated epoxy/glass hollow microsphere syntactic foams of various densities via buoyancy method [30]. Table 2 shows the all production methods along with their virtues and handicaps in detail.

\subsection{Macro and Micro Properties}

AMSFs are hollow or porous particle filled composites and can be considered as advanced engineering materials. General interest for these foams has been rising lately owing to their low density within a close range $\left(1-2.2 \mathrm{~g} / \mathrm{cm}^{3}\right)$. Table

Table 3. AMSF densities obtained with unlike foam components

\begin{tabular}{|c|c|c|c|c|}
\hline Study & Matrix & Filler Type & Filler Size & $\begin{array}{c}\text { Density (g/ } \\
\left.\mathrm{cm}^{3}\right)\end{array}$ \\
\hline Zhao, 2009 [10] & Al 6082 & Ceramic $\left(\mathrm{SiO}_{2}-\mathrm{Al}_{2} \mathrm{O}_{3}\right)$ & $75-125 \mu \mathrm{m}$ & $1,14-1,41$ \\
\hline Gupta, 2013 [8] & A356 & $\mathrm{SiC}$ & $1 \mathrm{~mm}$ & 1,81 \\
\hline Gupta, 2015 [12] & A356 & Alumina & $3 \mathrm{~mm}$ & $1,62-2,11$ \\
\hline Mondal, 2017 [25] & LM13 & Cenosphere & $\begin{array}{c}100-212 \\
\mu \mathrm{m}\end{array}$ & $1,9-2$ \\
\hline Taherishargh, 2014 [19] & A356 & Expanded perlite & $3-4 \mathrm{~mm}$ & $1,05-1,13$ \\
\hline Dou, 2007 [7] & Pure Al & Cenosphere & $\begin{array}{c}90-150 \\
\mu \mathrm{m}\end{array}$ & $1,43-1,52$ \\
\hline Gupta, 2006 [31] & A356 & Cenosphere & $\begin{array}{c}45-250 \\
\mu \mathrm{m}\end{array}$ & 1,25 \\
\hline Zhao, 2007 [17] & Pure Al & Glass sphere & $0,5-4 \mathrm{~mm}$ & $1,58-1,88$ \\
\hline Orbulov, 2013 [32] & AlSi12 & $\begin{array}{c}\text { Ceramic }\left(\mathrm{SiO}_{2}-\mathrm{A}-\right. \\
\left.\mathrm{I}_{2} \mathrm{O}_{3}-\text { Mullite }\right)\end{array}$ & $150 \mu \mathrm{m}$ & 1,35 \\
\hline Castro, 2013 [33] & Al 2024 & Alumina & $\begin{array}{c}3-4,25 \\
\mathrm{~mm}\end{array}$ & 1,25 \\
\hline Zhao, 2019 [34] & Al 6082 & Ceramic $\left(\mathrm{SiO}_{2}-\mathrm{Al}_{2} \mathrm{O}_{3}\right)$ & $\begin{array}{c}75-500 \\
\mu \mathrm{m}\end{array}$ & $1,40-2,29$ \\
\hline Puga, 2018 [35] & AlSi7Mg & Expanded clay & $2-7,5 \mathrm{~mm}$ & $1,27-1,45$ \\
\hline Goel, 2019 [36] & Al 2014 & Cenosphere & $\begin{array}{c}75-150 \\
\mu \mathrm{m}\end{array}$ & $1,85-1,88$ \\
\hline Orbulov, 2015 [37] & AlCu5 & $\begin{array}{c}\text { Ceramic ( } \mathrm{SiO}_{2}-\mathrm{A} \text { - } \\
\mathrm{I}_{2} \mathrm{O}_{3}-\text { Mullite) }\end{array}$ & $1,45 \mathrm{~mm}$ & 1,84 \\
\hline Zhang, 2016 [38] & Pure Al & Cenosphere & $\begin{array}{c}80-160 \\
\mu \mathrm{m}\end{array}$ & $1,43-1,52$ \\
\hline Fiedler, 2018 [39] & A356 & Expanded perlite & $3-4 \mathrm{~mm}$ & $1,06-1,11$ \\
\hline Mondal, 2009 [40] & Al 2014 & Cenosphere & $84 \mu \mathrm{m}$ & $1,5-1,9$ \\
\hline Taherishargh, 2015 [5] & A356 & Pumice & $2,8-4 \mathrm{~mm}$ & $1,48-1,5$ \\
\hline Zhang, 2016 [16] & $5 A 06$ & Cenosphere & $15-75 \mu \mathrm{m}$ & $1,17-1,32$ \\
\hline Schultz, 2013 [23] & A206 & $\mathrm{SiC}$ & $1 \mathrm{~mm}$ & $1,87-1,95$ \\
\hline Szlancsik, 2018 [41] & A356 & Expanded perlite & $3-4 \mathrm{~mm}$ & $0,7-1.1$ \\
\hline Kadar, 2019 [42] & Pure Al & Expanded perlite & $1-2 \mathrm{~mm}$ & 1,1 \\
\hline Mondal, 2018 [46] & Al 2014 & Alumina & $1 \mathrm{~mm}$ & $1,72-2,27$ \\
\hline
\end{tabular}

3 shows density values of some AMSFs fabricated with different techniques and particle sizes. Filler materials, for instance; alumina/glass spheres, fly-ash cenospheres, carbide spheres, expanded ceramic spheres and other porous rock particles, are majorly responsible for density diminishment and they also control total porosity ratio of the foam [10], [18].

Fly ash cenospheres are commonly preferred by investigators because of their cheapness and easy attainability. Indeed, ashes created from thermal power plants are recycled as cenosphere particles and thanks to benefication process, low density flawless cenospheres can be sorted out for production [11]. Although they are more expensive than other porous alternatives like expanded glass, perlite and pumice, hollow spheres of $\mathrm{Al}_{2} \mathrm{O}_{3}, \mathrm{SiC}$, and $\mathrm{SiO}_{2}$ have high porosity due to their very thin outer shell. Engineered hollow spheres usually perform better than fly ash cenospheres in terms of compressive behavior, however, according to some studies, natural based cellular particles (i.e. expanded glass and pumice) can be considered as promising alternatives [5], [19]. From milimeter to micrometers, all reinforcements have to possess non-damaged and smooth outer surface, otherwise molten matrix may leak into the fillers, which triggers density rise. Low wettability of the fillers may cause casting cavities around matrix-filler interfaces, which affects mechanical responses in a noteworthy manner.

During the fabrication, enough wettability of the filler particles is highly important that determines envelopment quality of the fillers by $\mathrm{Al}$ matrix. Filler roundness effects wettability in a positive manner, but some investigations also shows that complex porous fillers can be used effectively with a good wettability [19], [39], [41]. In Fig. 3, two types of the AMSF (Al 7075/hollow alumina with 1,7 g/ $\mathrm{cm}^{3}$ density and $\mathrm{Al} 7075 /$ porous pumice with $1,5 \mathrm{~g} / \mathrm{cm}^{3}$ density) having perfect reinforcement/matrix harmony are demonstrated in detail.

A wide range of $\mathrm{Al}$ alloys have been used in diversified industries for a long time and they basically are divided into two groups: heat treatable and work hardened alloys [13], [43]. Cp-Al, A356, A380, 2014, 6061 and 7075 series are frequently preferred matrices for AMSFs since some of them are suitable for infiltration with good viscosity and the others are heat treatable after the fabrication. Depending on filler/matrix combination and fabrication conditions, certain chemical reactions written below may occur between matrix and filler, especially particle with high $\mathrm{SiO}_{2}[44]$.

$$
4 \mathrm{Al}_{(\mathrm{l})}+3 \mathrm{SiO}_{2(\mathrm{~s})}=3 \mathrm{Si}_{(\mathrm{s})}+2 \mathrm{Al}_{2} \mathrm{O}_{3(\mathrm{~s})} \quad\left(700-850^{\circ} \mathrm{C}\right)
$$

In this chemical activity, amorphous $\mathrm{SiO}_{2}$ in the filler composition can transform to crystalline $\mathrm{Al}_{2} \mathrm{O}_{3}$ which leads to zonal stiffness increment at the matrix/filler interfaces. Besides, syntactic foam density may go up due to probability of filler wall declination and total porosity of the foam may diminish. By avoiding high melting temperature and applying rapid solidification that kinds of adverse effects of this 
reaction can be minimized or completely blocked.

Characteristic microstructure of the AMSF can be seen in Fig. 4 with combination of both theoretical and a few real images.

$\mathrm{Al}$ alloy and filler materials with huge close gaps or porosity compose main part of the microstructure, however, based on matrix/filler match and process variables, some fillers may exhibit combining tendency or may cracked from outer walls [17], [31], [45]. This situation results in molten matrix leakage into inner gaps of the fillers and can dominate fracture style of the foam. Moreover, during solidification stage, by reason of different thermal conductivity of the filler and matrix alloys small casting voids or shrinkage cavities can be beheld around matrix/filler interface [11], [31].

Aforementioned micro properties are typical for AMSFs and considerably decisive on the mechanical behaviors by altering deformation/fracture style. Then, if the other kinds of MMSFs like Fe, Mg or Zn matrix foams are examined, similar microstructures with AMSFs can be detected easily
[47-52]. Aside from fabrication conditions and matrix/filler features, heat treatment of $\mathrm{Al}$ matrix should also be taken into consideration from the point of microstructure of the AMSF which directly affects matrix phase formation [5355].

\subsection{Mechanical Properties}

AMSF can be described as an advance particle reinforced composite owing to its physical formation, but, at the same time, it has close cell foam structure by way of added hollow/ porous reinforcements. Filler materials play an important role on the mechanical features of the AMSF as they provide almost all of the foam porosity. Type of the $\mathrm{Al}$ alloy, chemical composition of the filler, pore condition of the particles (hollow or porous), size range of the filler, fabrication style, process parameters and heat treatment are other effective variables determining the mechanical responses. AMSFs are designed to be utilized under compressive loadings and existing efforts in the literature usually focus on their low (quasi-static) and high speed compression properties. In

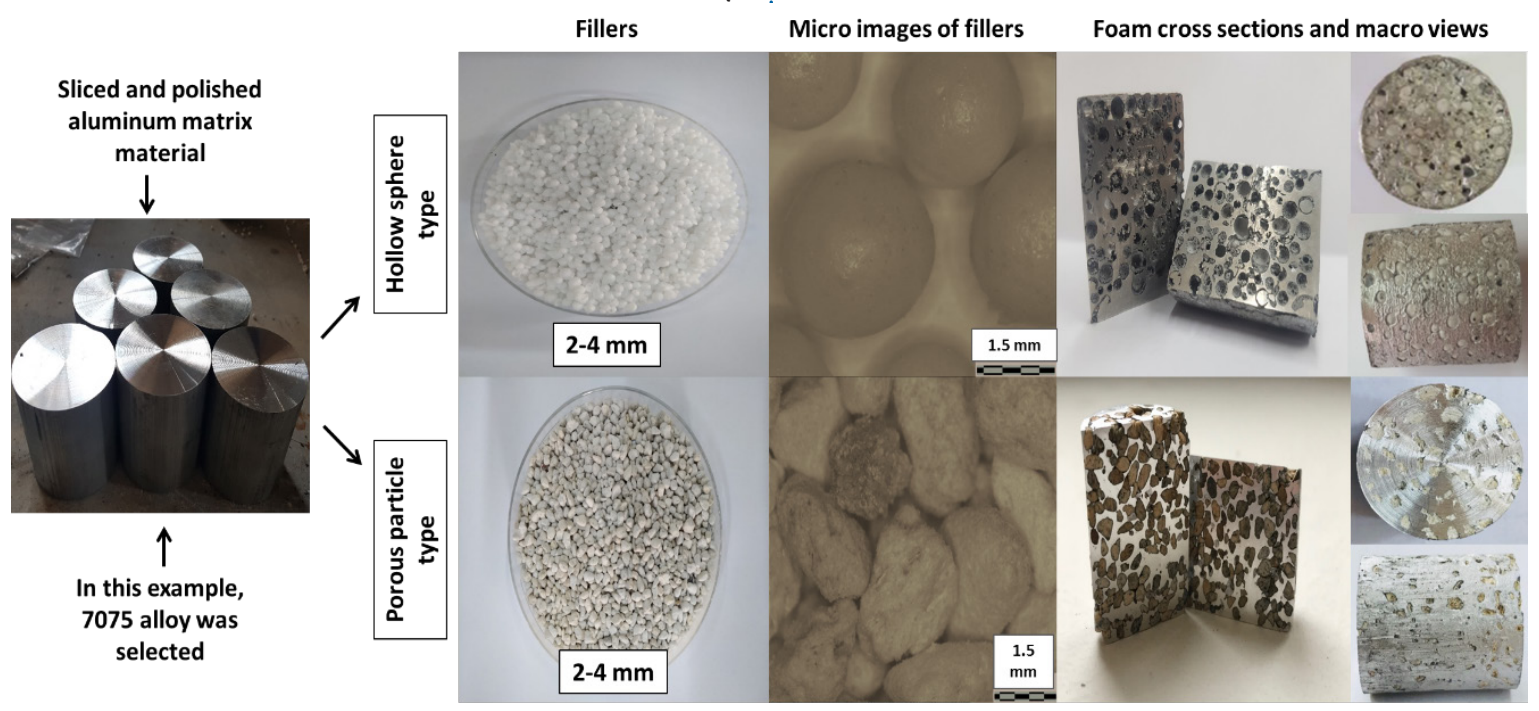

Figure 3. Physical analysis of different Al 7075 syntactic foams

Real optical micro views of some AMSF samples

Theoretical inner structure of AMSF

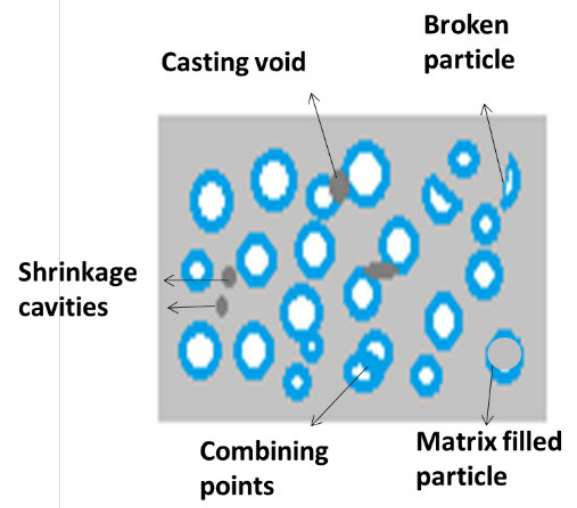

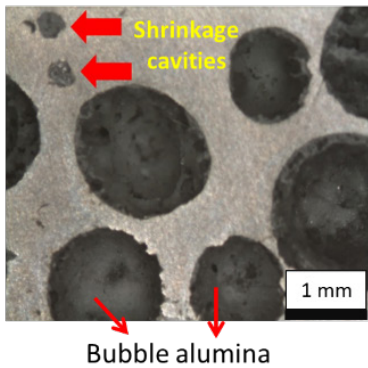
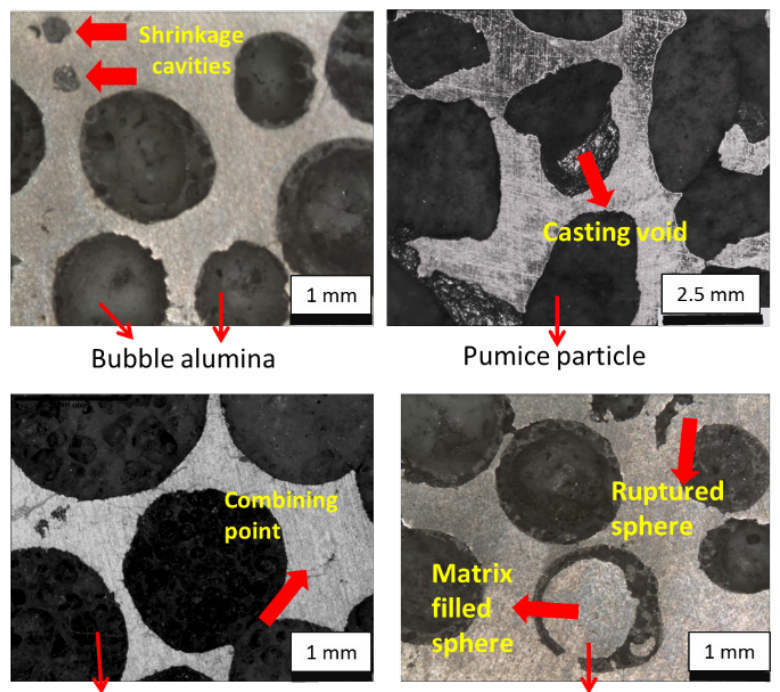

Expanded glass sphere

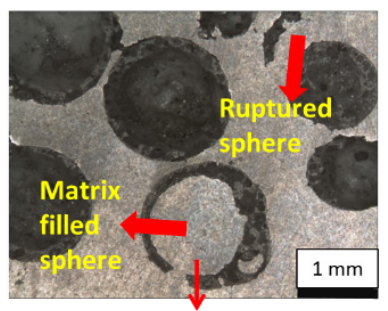

Bubble alumina

Figure 4. Characteristic microstructure of the AMSFs 
order to correct interpretation of the features, ISO 13314 standard is availed by researchers [56]. Since filler particles are engineered ceramics or hard natural rock fragments with high modulus and stiffness, compressive load is largely carried by these elements during the deformation. Fig. 5 shows an example for determination of mechanical features according to ISO 13314. The slope of the linear area is the quasi-elastic gradient (QEG) and $1 \%$ offset yield stress is accepted as compression strength $\left(\sigma_{\text {com }}\right)$. Plateau stress $\left(\sigma_{\mathrm{plt}}\right)$ is the arithmetic mean of the stress values between $20 \%$ and $40 \%$ strain. Also, densification strain $\left(\varepsilon_{\text {den }}\right)$ is corresponding strain for 1,3 times plateau stress and $\mathrm{W}$ is the absorbed energy that is calculated from area under the stress/strain curve up to $\% 50$ strain.

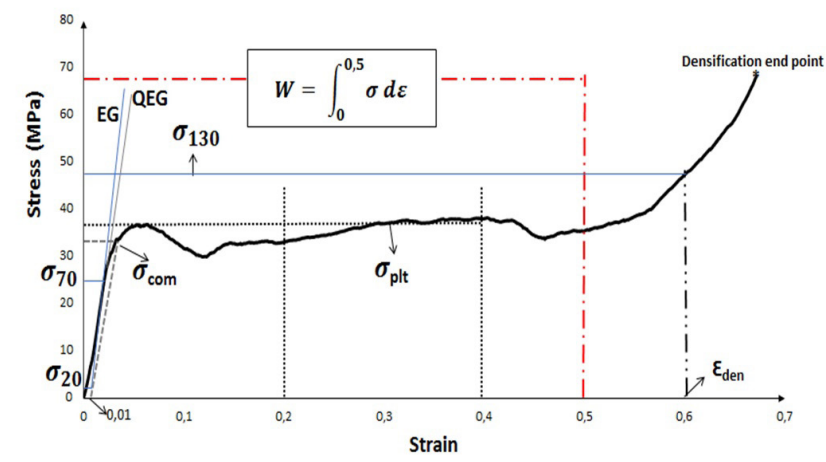

Figure 5. Interpretation of ISO 13314 standard

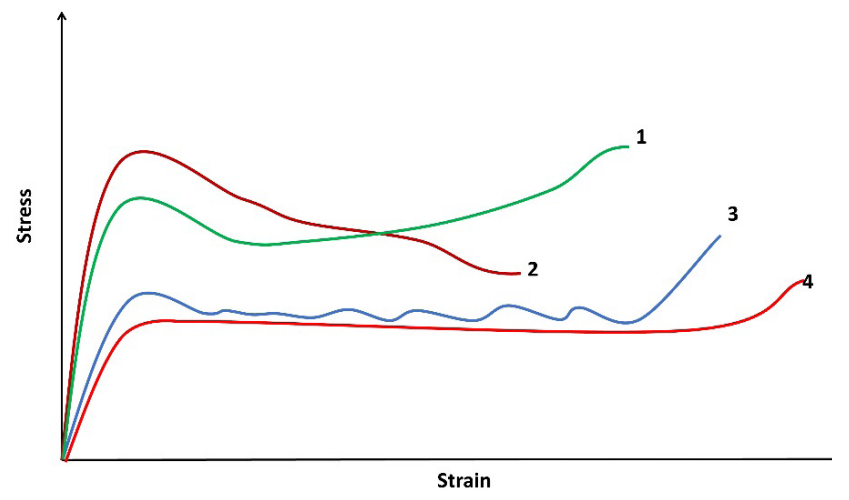

Figure 6. Probable stress/strain graphs for AMSF

After the mechanical observations, researchers emphasize that different kinds of stress/strain curves imaged in Fig. 6 might occur depending upon filler pore structure and $\mathrm{Al}$ alloy type. For instance, due to strain hardening and heat treatment, curve 1 has an increasing plateau trend although curve 2 exhibits declining trend. Curve 3 represents $\mathrm{Al}$ syntactic filled with porous/cellular reinforcement and curve 4 belongs to ideal theoretical behavior with perfect plateau region. Table 4 points main mechanical features of some AMSFs fabricated in earlier studies in terms of loading conditions. Usually, there are two principle deformation styles for AMSFs based on filler structure and strength of $\mathrm{Al}$ alloy [22], [57]. If the flow strength of $\mathrm{Al}$ alloy is lower than filler crush strength, type 1 deformation depicted in Fig. 7 is seen. Characteristic features of this kind of deformation are barreling effect and good elongation till the densification. Conversely, if the flow strength of matrix alloy is higher than

filler crush strength, type 2 deformation is beheld. Usually, after the type 1 deformation, foam samples remain majorly monolithic and only small fragments break out from the main composite body. However, as for the type 2, typically, $45^{\circ}$ shear bands and major deep cracks with low elongation are clear evidences and foam samples often divide into two or more discrete sections.

Table 4. Literature data for the mechanical features of AMSFs

\begin{tabular}{|c|c|c|c|c|c|}
\hline Study & $\begin{array}{c}\text { Deformation } \\
\text { type }\end{array}$ & Foam Components & $\sigma_{\text {com }}(\mathrm{MPa})$ & $\sigma_{\text {plt }}(\mathrm{MPa})$ & $\varepsilon_{\text {den }}$ \\
\hline Gupta [8] & Quasi-static & A356/SiC & 181 & 126 & 0,45 \\
\hline Gupta [8] & Dynamic & A356/SiC & 130 & * & ${ }^{*}$ \\
\hline Zhao [10] & Quasi-static & $\mathrm{Al} 6082 / \mathrm{SiO}_{2}-\mathrm{Al}_{2} \mathrm{O}_{3}$ & 53,3 & 63,7 & 0,43 \\
\hline Gupta [12] & Quasi-static & $\mathrm{A} 356 / \mathrm{Al}_{2} \mathrm{O}_{3}$ & 106,5 & 62,8 & 0,6 \\
\hline Gupta [12] & Dynamic & $\mathrm{A} 356 / \mathrm{Al}_{2} \mathrm{O}_{3}$ & 164 & $*$ & ${ }^{*}$ \\
\hline $\begin{array}{c}\text { Taherishargh } \\
{[5]}\end{array}$ & Quasi-static & A356/Pumice & 47 & 65 & 0,45 \\
\hline Orbulov [57] & Quasi-static & Al99,5/Globocer & 50 & 51 & ${ }^{*}$ \\
\hline Orbulov [57] & Quasi-static & AlSi12/Globocer & 114 & 57 & ${ }^{*}$ \\
\hline $\mathrm{Wu}[58]$ & Quasi-static & $\begin{array}{c}\text { Al } 6061 / \text { Cenosphe- } \\
\text { re }\end{array}$ & 45 & 40,5 & 0,5 \\
\hline $\mathrm{Wu}[58]$ & Dynamic & Al 6061/Cenosphere & 55 & * & * \\
\hline Schultz [59] & Dynamic & $\mathrm{A} 380 / \mathrm{Al}_{2} \mathrm{O}_{3}$ & 120 & $*$ & ${ }^{*}$ \\
\hline $\begin{array}{c}\text { Taherishargh } \\
\text { [19] }\end{array}$ & Quasi-static & $\begin{array}{l}\text { A356/Expanded } \\
\text { perlite }\end{array}$ & 37,2 & 44,7 & 0,59 \\
\hline Zhao [17] & Quasi-static & $\mathrm{cp}-\mathrm{Al} / \mathrm{SiO}_{2}-\mathrm{Al}_{2} \mathrm{O}_{3}$ & * & 41,7 & 0,3 \\
\hline Weise [18] & Quasi-static & $\begin{array}{c}\text { AlSi9Cu3/Glass } \\
\text { bubble }\end{array}$ & 190 & 180 & 0,45 \\
\hline Zhang [38] & Quasi-static & $\mathrm{cp}-\mathrm{Al} /$ Cenosphere & 64,7 & 60,8 & 0,37 \\
\hline Zhang [38] & Dynamic & cp-Al/Cenosphere & 106,5 & * & * \\
\hline Hao [60] & Quasi-static & $\mathrm{ZL} 111 / \mathrm{Al}_{2} \mathrm{O}_{3}$ & 61,8 & 56,4 & 0,44 \\
\hline Hao [60] & Quasi-static & $\mathrm{cp}-\mathrm{Al} / \mathrm{Al}_{2} \mathrm{O}_{3}$ & 61,5 & 46,5 & 0,46 \\
\hline $\begin{array}{c}\text { Akinwekomi } \\
{[61]}\end{array}$ & Quasi-static & cp-Al/Cenosphere & 38,6 & 26,8 & 0,6 \\
\hline Goel [36] & Dynamic & Al 2014/Cenosphere & 572 & * & 0,4 \\
\hline
\end{tabular}
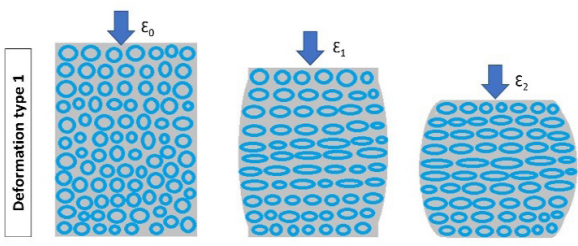

$\neg \varepsilon_{0}$
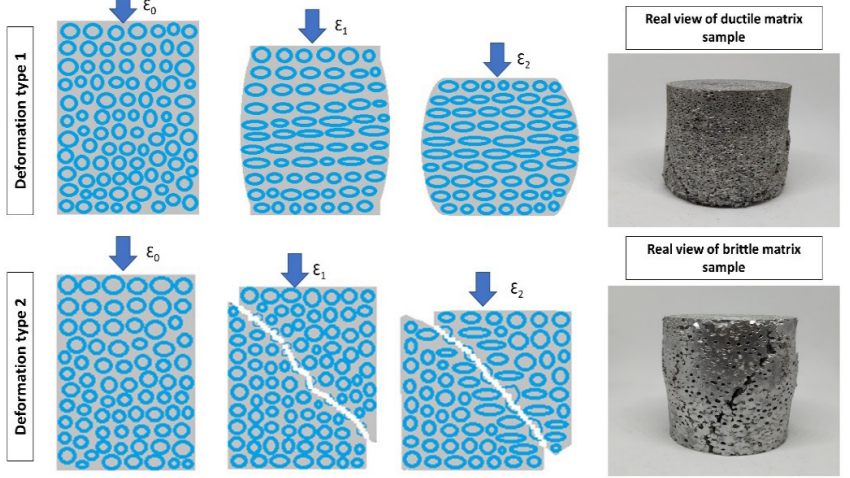

Figure 7. Main failure mechanisms of AMSF samples under compression

Aside from compressive properties, recently, some researchers focus on other loading types like fatigue and notch sensitivity [41], [62- 64]. Orbulov et al. worked on fatigue behavior of different AMSFs and they claimed that matrix ductility and filler diameter strongly affected the fatigue response [65]. Guan et al. measured impact response of $\mathrm{Al}$ 7075/ceramic foam by performing drop weight test and stated that $\mathrm{Al}$ and big size fillers combination exhibited better results [66]. In the light of these valuable efforts, it is highly possible that many other modes of loadings such as fatigue, creep, low temperature loading and bending will be investi- 
gated for AMSF in the upcoming years.

\section{POSSIBLE FUTURE APPLICATIONS}

High porosity engineering metals are typically classified as conventional metal foams ( $\mathrm{Al}, \mathrm{Mg}$, Ti metal foams etc.) and syntactic foams (metal + ceramic filler). Owing to their unique properties, traditional $\mathrm{Al}$ foams and $\mathrm{Al}$ matrix syntactic foams are designated for similar application purposes like high specific weight, high stiffness, perfect compression strength, good damping isolation, high energy absorption capacity, vibration isolation and fine acoustic features [2], [67-68]. In today's competitive industrial world, from automotive and aviation to aerospace and construction, many sectors endeavor to drop manufacturing cost without sacrificing quality, so advanced engineering materials such as composites, foams and syntactic foams have become more attractive for many companies [2],[11],[14], [69-73]. Standard $\mathrm{Al}$ foams have pores stemming from some gases which reduce weight [68], [74-76], but it may cause some handicaps like difficulties in controlling the size and shape of the pores. AMSFs have big potential for real applications because they are not only lighter than traditional particle reinforced $\mathrm{Al}$ composites but they also response better than conventional $\mathrm{Al}$ foams in mechanical loadings due to their uniform size/ shape distribution.

Along with the increasing awareness of environmental pollution and solid rules on total gas emission, the automotive industry is striving to solve total weight and fuel efficiency problems. In this context, it is true to say that AMSFs, which can be used as pillars, crash boxes or other structural components in a car, can fulfill mechanical requirements illustrated in Fig. 8 as well as total weight reduction.

Likewise automotive, aerospace and aviation industries also attach importance to fuel efficiency, lightweight vehicle construction and perfect mechanical properties. For instance, in the 1970s, Concorde airplanes were built solely with \%7 fiber reinforced composites [77], but today, according to Giurgiutiu [78], Boeing 737 aircraft is widely composed of lightweight composite materials (\% 80 by volume). In a similar vein, another aircraft-maker Airbus also prefers advanced composite materials for aircraft fuselage parts and wing structures [79]. AMSFs, particularly as single body parts in the wings and core material for sandwich composites in the fuselage, may be an alternative to traditional composites in aircrafts and other air vehicles. They are notably lighter than fiber reinforced composites and can absorb more energy during deformation in case of undesired plane crashes. Aircraft wings are produced with specific types of $\mathrm{Al}$ alloys offering a combination of lightness and strength comparable to other kinds of metals. Herein, as a consequence of AMSF investigations, it can be alleged that this advanced foam might be an even better material and more appealing from the points of safety and fuel efficiency by the reason of its unique low density and plateau behavior.

Even though different casting techniques are applied for AMSF fabrication, in order to manufacture complex shapes and bigger geometries, we consider that some advanced casting techniques or secondary machining are strongly needed for real applications. Lately, researchers worked on machining of Al matrix composites to obtain complex final shapes via certain advanced manufacturing methods like abrasive water-jet cutting/turning, electrical discharge machining, laser cutting and ultrasonic machining [80-87]. On account of its perfect cutting/turning quality and availability for wide range of materials, abrasive water-jet system can be considered for final shaping of AMSF in the next years. Compared to other methods, water-jet systems provides better surface quality and dimensional accuracy without any thermal effects in the microstructure that may emerges in laser machining. Furthermore, regardless of filler type, by optimizing the process parameters of stand-off distance, traverse speed, water pressure, impact angle, abrasive type and size, all versions of AMSFs can be cut and turned with water-jet.

Apart from its outstanding mechanical properties, AMSF has also a potential of sound insulation as well as low thermal conduction owing to its high porosity. Therefore, there is no inconvenience to assert that thanks to these characteristic properties, in the upcoming period it will be more alluring for researchers and engineers working on several

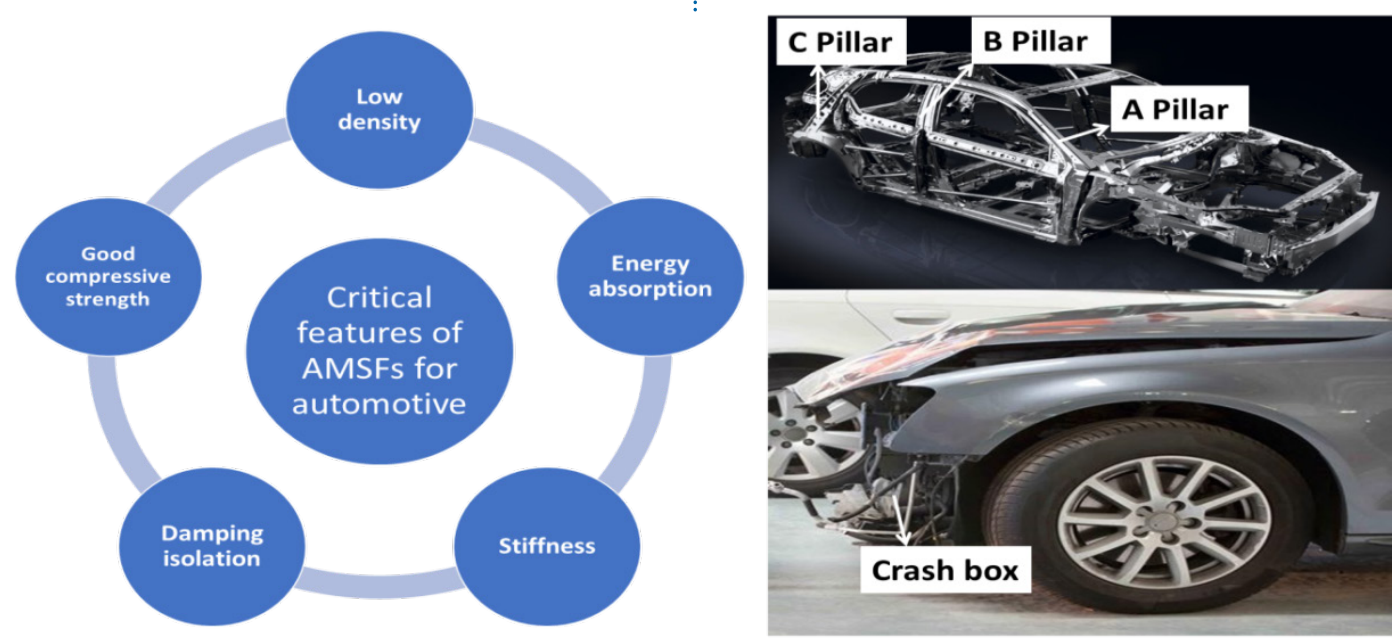

Figure 8. Probable AMSF application examples for automotive sector 
industrial areas.

\section{5. CONCLUSION}

In this paper, AMSF materials were reviewed elaborately with regards to their fabrication, physical features and mechanical responses by collecting and comparing many different literature studies. Moreover, we aimed to bring out some application suggestions for probable future works. As a result of our effort, the followings given below can be put in order;

- AMSF is an advanced engineering material having both foam and composite nature due to hollow or porous ceramic filler materials.

- For AMSF fabrication, infiltration casting and dispersion casting techniques are preferred by majority of the researchers although powder metallurgical ways recently have been investigated.

- By the reason of the fact that AMSFs have low density, perfect plateau behavior, good energy absorption ability and high ductility, they performs perfect under the compressive loadings.

- Along with their quasi-static behaviors, AMSFs also display outstanding mechanical performance under the high strain rate deformation. This situation is highly promising for their impact loading and damping isolation applications.

- Apart from their compressive properties, other types of loadings like fatigue, bending and creep have not been studied decently on AMSFs and we consider that this may alter in the immediate future.

- Almost all of the AMSF fabrication studies have been carried out on a lab scale and limited with simple cylindrical shape, however, in order to meet the requirements of industrial applications, some secondary machining processes or advanced casting techniques should be analyzed in the upcoming years.

- Compared to other sectors, automotive, aviation and construction industries are the most remarkable candidates for real applications of the AMSF. Together with the increasing studies about AMSFs, it is considerably possible that real AMSF parts will appear in land vehicles, aircrafts and modern buildings.

\section{REFERENCES}

[1] Acoustic Properties of Syntactic Foam - Part 2 (2020). Retrieved on February 10, 2020, from https://esyntactic.com/acoustic-properties-of-syntactic-foam-part-2/.

[2] Orbulov, I. N., Szlancsik, A. (2018). On the mechanical properties of aluminum matrix syntactic foams. Advanced Engineering Materials, 20(5), 1700980. doi:10.1002/adem.201700980.

[3] Gupta, N., Rohatgi, K. (2015). Metal Matrix Syntactic Foams:Processing, Microstructure, Properties and Applications. Lancaster, USA.
[4] Szlancsik, A., Katona, B., Májlinger, K., Orbulov, I.N. (2015). Compressive behavior and microstructural characteristics of iron hollow sphere filled aluminum matrix syntactic foams. Materials, 8 (11): 7926-7937. doi:/10.3390/ma8115432.

[5] Taherishargh, M., Belova, I.V., Murch, G.E., Fiedler, T. (2015). Pumice/ aluminium syntactic foam. Materials Science \& Engineering A, 635: 102-108. doi:10.1016/j.msea.2015.03.061.

[6] Ferguson, J.B, Santa Maria, J.A., Schultz, B.F., Rohatgi, P.K. (2013). AlAl2O3 syntactic foams_-Part II: Predicting mechanical properties of metal matrix syntactic foams reinforced with ceramic spheres. Materials Science \& Engineering A, 582: 423-432. doi:10.1016/j. msea.2013.06.065.

[7] Wu, G.H., Dou, Z.Y., Sun, D.L. Jiang, L.T. Ding, B.S. He, B.F. (2007). Compression behaviors of cenosphere-pure aluminum syntactic foams. Scripta Materialia, 56 (3): 221-224. doi:10.1016/j.scriptamat.2006.10.008.

[8] Luong, D.D., Strbik III, O.M., Hammond, V.H., Gupta, N., Cho, K. (2013). Development of high performance lightweight aluminum alloy/SiC hollow sphere syntactic foams and compressive characterization at quasi-static and high strain rates. Journal of Alloys and Compounds, 550: 412-422. doi: 10.1016/j.jallcom.2012.10.171.

[9] Al-Sahlani, K., Broxtermann, S., Lell, D., Fiedler, T. (2018). Effects of particle size on the microstructure and mechanical properties of expanded glass-metal syntactic foams. Materials Science and Engineering: A, 728: 80-87. doi:10.1016/j.msea.2018.04.103.

[10] Tao, X.F., Zhang, L.P., Zhao, Y.Y. (2009). Al matrix syntactic foam fabricated with bimodal ceramic microspheres. Materials and Design, 30: 2732-2736. doi:10.1016/j.matdes.2008.11.005.

[11] Gupta, N., Luong, D.D., Cho, K. (2012). Magnesium matrix composite foams - density, mechanical properties, and applications. Metals 2 (3): 238-252. doi:/10.3390/met2030238.

[12] Licitra, L., Luong, D.D., Strbik III, O.M., Gupta, N. (2015). Dynamic properties of alumina hollow particle filled aluminum alloy A356 matrix syntactic foams. Materials and Design, 66 (B): 504-515. doi:10.1016/j.matdes.2014.03.041.

[13] ASM Handbook Committee (1991). Heat Treating of Aluminum Alloys. USA.

[14] Banhart, J. (2003). Aluminum foams: On the road to real applications. MRS Bulletin, 28 (4): 290-295, doi:10.1557/mrs2003.832003.

[15] Zhang, Q., Lee, P.D., Singh, R., Wu, G., Lindley, T.C. (2009). Micro-CT characterization of structural features and deformation behavior of fly ash/aluminum syntactic foam. Acta Materialia 57: 3003-3011. doi:10.1016/j.actamat.2009.02.048.

[16] Lin, Y., Zhang, Q., Xiangyu M., Wu, G. (2016). Mechanical behavior of pure $\mathrm{Al}$ and $\mathrm{Al}-\mathrm{Mg}$ syntactic foam composites containing glass cenospheres. Composites: Part A, 87: 194-202. doi:10.1016/j.compositesa.2016.05.001

[17] Zhang, L.P. and Zhao, Y.Y. (2007). Mechanical response of Al matrix syntactic foams produced by pressure infiltration casting. Journal of Composite Materials, 41 (17): 2105-2117. doi: $10.1177 / 0021998307074132$.

[18] Weise, J., Zanetti-Bueckmann, V., Yezerska, O., Schneider, M. Haesche, M. (2007). Processing, properties and coating of micro-porous syntactic foams. Advanced Engineering Materials, 9 (1-2): 5256. doi:10.1002/adem.200600198.

[19] Taherishargh, M., Belova, I.V., Murch, G.E, Fiedler, T. Low-density expanded perlite-aluminium syntactic foam. Materials Science \& Engineering A, 604: 127-134. doi:10.1016/j.msea.2014.03.003. 
[20] Palmer, R.A., Gao, K., Doan, T.M., Green, L., Cavallaro, G. (2007). Pressure infiltrated syntactic foams-Process development and mechanical properties', Materials Science and Engineering: A, 464 (1-2): 85-92. doi:10.1016/j.msea.2007.01.116.

[21] Orbulov, I.N., Dobránszky, J. (2008). Producing metal matrix syntactic foams by pressure infiltration. Mechanical Engineering, 52 (1): 35-42. doi:10.3311/pp.me.2008-1.06.

[22] Balch, D.K., O'Dwyer, J.G., Davis, G.R., Cady, C.M., Gray III, G.T., Dunand, D.C. (2005). Plasticity and damage in aluminum syntactic foams deformed under dynamic and quasi-static conditions. Materials Science and Engineering A, 391: 408-417. doi:10.1016/j. msea.2004.09.012.

[23] Rivero, G.A.R., Schultz, B.F., Ferguson, J.B., Gupta, N., Rohatgi, P.K. (2013). Compressive properties of Al-A206/SiC and Mg-AZ91/SiC syntactic foams. Journal of Materials Research, 28 (17): 2426-2435. doi:10.1557/jmr.2013.176.

[24] Sahu, S., Zahid Ansari, M., Mondal, D.P. (2020). Microstructure and compressive deformation behavior of 2014 aluminium cenosphere syntactic foam made through stircasting technique. Materials Today. doi:10.1016/j.matpr.2019.09.019.

[25] Vishwakarma, A., Mondal, D.P., Birla, S., Das, S., Prasanth N. (2017). Effect of cenosphere size on the dry sliding wear behaviour LM13-cenosphere syntactic foam. Tribology International, 110: 8-22. doi:10.1016/j.triboint.2017.01.041.

[26] Birla, S., Mondal, D.P., Das, S., Khare, A., Jai Prakash S. (2017). Effect of cenosphere particle size and relative density on the compressive deformation behavior of aluminum-cenosphere hybrid foam. Materials \& Design, 117: 168-177. doi:10.1016/j.matdes.2016.12.078.

[27] Daoud, A. (2008). Synthesis and characterization of novel ZnAl22 syntactic foam composites via casting. Materials Science and Engineering: A, 488 (1-2): 281-295. doi:10.1016/j.msea.2007.11.020.

[28] Daoud, A., Abou El-khair, M.T., Abdel-Aziz, M., Rohatgi, P. (2007). Fabrication, microstructure and compressive behavior of ZC63 Mgmicroballoon foam composites. Composites Science and Technology, 67 (9): 1842-1853. doi:10.1016/j.compscitech.2006.10.023.

[29] Ferreira, S.C., Velhinho, A., Silva, R.J.C. (2010). Corrosion behaviour of aluminium syntactic functionally graded composites. International Journal of Materials and Product Technology.

[30] Kim, H.S. and Plubrai, P. (2004). Manufacturing and failure mechanisms of syntactic foam under compression. Composites Part A: Applied Science and Manufacturing, 35 (9): 1009-1015. doi:10.1016/j. compositesa.2004.03.013.

[31] Rohatgi, P.K., Kim, J.K., Gupta, N., Alaraj, S., Daoud, A. (2006). Compressive characteristics of A356/fly ash cenosphere composites synthesized by pressure infiltration technique. Composites Part A: Applied Science and Manufacturing, 37: 430-437. doi:10.1016/j. compositesa.2005.05.047.

[32] Orbulov, I.N. (2013). Metal matrix syntactic foams produced by pressure infiltration - The effect of infiltration parameters. Materials Science \& Engineering A, 583: 11-19. doi:10.1016/j.msea.2013.06.066.

[33] Castro, G., Nutt, S.R., Wenchen, X. (2013). Compression and low-velocity impact behavior of aluminum syntactic foam. Materials Science \& Engineering A, 578: 222-229. doi:10.1016/j.msea.2013.04.081.

[34] Zhang, Y. and Zhao, Y. (2019). Hysteretic energy dissipation in aluminium matrix syntactic foam under intermittent cyclic compression. Materialia, 6. doi:10.1016/j.mtla.2019.100286.

[35] Puga, H., Carneiro, V.H., Jesus, C., Pereira, J., Lopes, V. (2018). Influence of particle diameter in mechanical performance of Al expanded clay syntactic foams. Composite Structures, 184: 698-703. doi:10.1016/j. compstruct.2017.10.040.

[36] Goel, M.D., Parameswaran, V., Mondal, D.P. (2019). High strain rate response of cenosphere-filled aluminum alloy syntactic foam. Journal of Materials Engineering and Performance, 28: 4731-4739. doi:10.1007/s11665-019-04237-2.

[37] Myers, K., Katona, B., Cortes, P., Orbulov, I.N. (2015). Quasi-static and high strain rate response of aluminum matrix syntactic foams under compression. Composites Part A: Applied Science and Manufacturing, 79: 82-91. doi:10.1016/j.compositesa.2015.09.018.

[38] Zhang, B., Lin, Y., Li, S., Zhai, D., Wu, G. (2016). Quasi-static and high strain rates compressive behavior of aluminum matrix syntactic foams. Composites Part B: Engineering, 98: 288-296. doi:10.1016/j. compositesb.2016.05.034.

[39] Taherishargh, M., Linul, E., Broxtermann, S., Fiedler, T. (2018). The mechanical properties of expanded perlite-aluminium syntactic foam at elevated temperatures. Journal of Alloys and Compounds, 737: 590-596. doi:10.1016/j.jallcom.2017.12.083.

[40] Mondal, D.P., Das, S., Ramakrishnan, N., Bhasker, K.U. (2009). Cenosphere filled aluminum syntactic foam made through stir-casting technique. Composites: Part A, 40 (3): 279-288. doi:10.1016/j.compositesa.2008.12.006.

[41] Szlancsik, A., Katona, B., Orbulov, I.N., Taherishargh M., Fiedler, T. (2018). Fatigue properties of EP/A356 aluminium matrix syntactic foams with different densities. IOP Conf. Series: Materials Science and Engineering, 426. doi:10.1088/1757-899X/426/1/012045.

[42] Kadar, C., Chmelík, F., Ugi, D., Máthis, K., Knapek, M. (2019). Damage characterization during compression in a perlite-aluminum syntactic foam. Materials 12 (20): 3342. doi:10.3390/ma12203342.

[43] Ashby, M.F., and Jones, D.R.H. (2013). Engineering Materials 2 An Introduction to Microstructures and Processing. USA.

[44] Balch, D.K., and Dunand, D.C. (2006). Load partitioning in aluminum syntactic foams containing ceramic microspheres. Acta Materialia, 54 (6):1501-1511. doi.10.1016/j.actamat.2005.11.017.

[45] Ferguson, J.B., Santa Maria, J.A., Schultz, B.F., Rohatgi, P.K. (2013). $\mathrm{Al}-\mathrm{Al} 2 \mathrm{O} 3$ syntactic foams-Part I: Effect of matrix strength and hollow sphere size on the quasi-static properties of Al-A206/Al2O3 syntactic foams. Materials Science \& Engineering A, 582: 415-422. doi:10.1016/.jmsea.2013.05.081.

[46] [46] Mondal, D.P., Goel, M.D., Upadhyay, V., Das, S., Singh M., Barnwal, A.K. (2018). Comparative study on microstructural characteristics and compression deformation behaviour of alumina and cenosphere reinforced aluminum syntactic foam made through stir casting technique. Transactions of the Indian Institute of Metals, 71: 567-577. doi:10.1007/s12666-017-1211-x.

[47] Movahedi, N., Murch, G.E., Belova I.V., Fiedler, T. (2019). Effect of heat treatment on the compressive behavior of zinc alloy ZA27 syntactic foam. Materials, 2019, 12 (5): 792. doi:10.3390/ma12050792.

[48] Castro, G. and Nutt, S.R. (2012). Synthesis of syntactic steel foam using gravity-fed infiltration. Materials Science and Engineering A, 553: 89- 95. doi:10.1016/j.msea.2012.05.097.

[49] Castro, G. and Nutt, S.R. (2012). Synthesis of syntactic steel foam using mechanical pressure infiltration. Materials Science and Engineering A, 535: 274- 280. doi:10.1016/j.msea.2011.12.084.

[50] Hartmann, M., Reindel, K., Singer, R.F. (1998). Fabrication and properties of syntactic magnesium foams. Mrs Online Proceedings, 521: 211. doi:10.1557/PROC-521-211.

[51] Anantharaman, H., Shunmugasamy, V.C., StrbikIII, O.M., Gupta, N., 
Cho, K. (2015). Dynamic properties of silicon carbide hollow particle filled magnesium alloy (AZ91D) matrix syntactic foams. International Journal of Impact Engineering, 82: 14-24. doi:10.1016/j. ijimpeng.2015.04.008.

[52] Weise, J., Lehmhus, D., Baumeister, J., Kun, R., Bayoumi, M., Busse, M. (2014). Production and properties of $316 \mathrm{~L}$ stainless steel cellular materials and syntactic foams, Steel Research International, 85 (3). doi:10.1002/srin.201300131.

[53] Marlaud, T., Deschamps, A., Bley, F., Lefebvre, W., Baroux, B. (2010). Influence of alloy composition and heat treatment on precipitate composition in $\mathrm{Al}-\mathrm{Zn}-\mathrm{Mg}-\mathrm{Cu}$ alloys. Acta Materialia, 58 (1): 248260. doi:10.1016/j.actamat.2009.09.003.

[54] Elangovan, K. and Balasubramanian, V. (2008). Influences of postweld heat treatment on tensile properties of friction stir-welded AA6061 aluminum alloy joints. Materials Characterization, 59 (9): 1168-1177. doi:10.1016/j.matchar.2007.09.006.

[55] Mahathaninwong, N., Plookphol, T., Wannasin, J., Wisutmethangoon, S. (2012). T6 heat treatment of rheocasting 7075 Al alloy. Materials Science and Engineering: A, 532: 91-99. doi:10.1016/j. msea.2011.10.068.

[56] ISO 13314, Switzerland, 2011.

[57] Katona, B., Szlancsik, A., Tábic, T., Orbulov, I.N. (2019). Compressive characteristics and low frequency damping of aluminium matrix syntactic foams. Materials Science \& Engineering A, 739: 140-148. doi:10.1016/j.msea.2018.10.014.

[58] Zou, L.C., Zhang, Q., Pang, B.J., Wu, G.H., Jiang, L.T., Su, H. (2013). Dynamic compressive behavior of aluminum matrix syntactic foam and its multilayer structure. Materials \& Design, 45: 555-560. doi:10.1016/j.matdes.2012.08.015.

[59] Santa Maria, J.A., Schultz, B.F, Ferguson, J.B., Gupta, N., Rohatgi, P.K (2014). Effect of hollow sphere size and size distribution on the quasi-static and high strain rate compressive properties of Al-A380Al2O3 syntactic foams. Journal of Materials Science, 49: 1267-1278. doi:10.1007/s10853-013-7810-y.

[60] Su, M., Wang, H., Hao, H. (2019). Compressive properties of aluminum matrix syntactic foams prepared by stir casting method. Advanced Engineering Materials, 21. doi:10.1002/adem.201900183.

[61] Akinwekomi, A.D., Adebisi, J.A., Adediran, A.A. (2019). Compressive characteristics of aluminum-fly ash syntactic foams processed by microwave sintering. Metallurgical and Materials Transactions A, 50: 4257-4260. doi:10.1007/s11661-019-05347-1.

[62] Szlancsik, A., Katona, B., Károly, D., Orbulov, I.N. (2109). Notch (In) Sensitivity of aluminum matrix syntactic foams. Materials, 2019, 12 (4): 574 . doi: $10.3390 / \mathrm{ma} 12040574$.

[63] Taherishargh, M., Katona, B., Fiedler, T., Orbulov, I.N. (2016). Fatigue properties of expanded perlite/aluminum syntactic foams. The Journal of Composite Materials, 51 (6): 773-781. doi:10.1177/0021998316654305

[64] Katona, B., and Orbulov, I.N. (2017). Structural damages in syntactic metal foams caused by monotone or cyclic compression. Periodica Polytechnica Mechanical Engineering, 61 (2): 146-152. doi:10.3311/ PPme.10346.

[65] Katona, B., Szebényi, G., Orbulov, I.N. (2017). Fatigue properties of ceramic hollow sphere filled aluminium matrix syntactic foams. Materials Science and Engineering: A, 679: 350-357. doi:10.1016/j. msea.2016.10.061.

[66] Altenaiji, M., Guan, Z.W., Cantwell, W.J., Zhao, Y., Schleyer, G.K. (2014). Characterisation of aluminium matrix syntactic foams under drop weight impact. Materials \& Design, 59: 296-302. doi:10.1016/j. matdes.2014.03.002.

[67] Sobczak, J. (2003). High Porosity Media for Transportation-Selected Aspects. Journal of KONES Internal Combustion Engines, 10.

[68] Ashby, M.F. (2000). Metal Foams: A Design Guide. USA.

[69] Ibrahim, I.A., Mohamed, F.A, Lavernia, E.J. (1991). Particulate reinforced metal matrix composites - a review. Journal of Materials Science, 26: 1137-1156.

[70] Bakshi, S.R., Lahiri, D., Agarwal, A. (2010). Carbon nanotube reinforced metal matrix composites - a review. Journal International Materials Reviews, 55 (1): 41-64. doi:10.1179/09506600 9X12572530170543.

[71] Pickering, K.L., Efendy, M.G.A., Le, T.M.A. (2016). Review of recent developments in natural fibre composites and their mechanical performance. Composites Part A: Applied Science and Manufacturing, 83: 98-112. doi:10.1016/j.compositesa.2015.08.038.

[72] Bains, P.S., Sidhu, S.S., Payal, H.S. (2016). Fabrication and machining of metal matrix composites: A Review. Materials and Manufacturing Processes, 31 (5): 553-573. doi:10.1080/10426914.2015.1025976.

[73] Rohatgi, P.K., Gupta, N., Schultz, B.F., Luong, D.D. (2011). The synthesis, compressive properties, and applications of metal matrix syntactic foams. Journal of Materials, 63: 36-42. doi:10.1007/s11837011-0026-1.

[74] Kennedy, A.R. (2002). The effect of $\mathrm{TiH} 2$ heat treatment on gas release and foaming in Al-TiH2 preforms. Scripta Materialia, 47 (11): 763-767. doi:10.1016/S1359-6462(02)00281-6.

[75] Haesche, M., Weise, J., Moreno, F.G., Banhart, J. (2008). Influence of particle additions on the foaming behaviour of AISi11/TiH2 composites made by semi-solid processing. Materials Science and Engineering: A, 480 (1-2): 283-288. doi:10.1016/j.msea.2007.07.040.

[76] Khabushan, J.K., Bonabi, S.B., Aghbagh, F.M., Khabushan, A.K. (2014). A study of fabricating and compressive properties of cellular Al-Si (355.0) foam using TiH2. Materials \& Design, 55: 792-797. doi:10.1016/j.matdes.2013.10.022.

[77] Khatib J. (2016). Sustainability of Construction Materials. UK.

[78] Giurgiutiu, V. (2016). Structural Health Monitoring of Aerospace Composites. USA.

[79] Guo, Q. (2018). Thermosets.

[80] Srivastava, A.K., Nag, A., Dixit, A.R., Tiwari, S., Scucka, J., Zelenak, M., Hloch, S., Hlavacek, P. (2017). Surface integrity in tangential turning of hybrid MMC A359/B4C/Al2O3 by abrasive waterjet. Journal of Manufacturing Processes, 28 (1): 11-20. doi:10.1016/j.jmapro.2017.05.017.

[81] Gnanavelbabu, A., Saravanan, P., Rajkumar, K., Karthikeyan, S., Baskaran, R. (2018). Effect of abrasive waterjet machining parameters on hybrid AA6061-B4C- CNT composites. Materials Today: Proceedings, 5 (5): 13438-13450. doi:10.1016/j.matpr.2018.02.338.

[82] Gnanavelbabu, A., Rajkumar, K., Saravanan, P. (2018). Investigation on the cutting quality characteristics of abrasive water jet machining of AA6061-B4C-hBN hybrid metal matrix composites. Materials and Manufacturing Processes, 33 (12): 1313-1323. doi:10.1080/104 26914.2018.1453146.

[83] Marimuthu, S., Dunleavey, J., Liu, Y., Antar, M., Smith, B. (2019). Laser cutting of aluminum-alumina metal matrix composite. Optics \& Laser Technology, 117: 251-259. doi:10.1016/j.optlastec.2019.04.029.

[84] Marimuthu, S., Dunleavey, J., Smith, B. (2019). Laser based machining of aluminum metal matrix composites. Procedia CIRP, 85: 243- 
248. doi:10.1016/j.procir.2019.09.007.

[85] Manikandan, N., Binoj, J.S., Varaprasad, K.C., Sabari, S.S., Raju, R. (2019). Investigations on wire spark erosion machining of aluminum-based metal matrix composites. Advances in Manufacturing Technology. doi:10.1007/978-981-13-6374-0_42.

[86] Ergene, B., and Bolat, C. (2019). A Review on the recent investigation trends in abrasive water jet cutting and turning of hybrid composites. Sigma Journal of Engineering \& Natural Sciences, 37 (3): 9891016.

[87] Uthayakumar, M., Babu, K.V., Kumaran, S.T., Kumar, S.S., Winowlin Jappes, J.T., Rajan, T.P.D. (2019). Study on the machining of Al-SiC functionally graded metal matrix composite using die-sinking EDM. Particulate Science and Technology, 37 (1): 103-109. doi:10.1 080/02726351.2017.1346020. 